Original Research Paper

\title{
Effect of Soil Types on Growth, Survival and Abundance of Mangrove (Rhizophora racemosa) and Nypa Palm (Nypa fruticans) Seedlings in the Niger Delta, Nigeria
}

\author{
Aroloye O. Numbere \\ Department of Animal and Environmental Biology, University of Port Harcourt, Choba, Nigeria
}

\author{
Article history \\ Received: 27-12-2018 \\ Revised: 08-04-2019 \\ Accepted: 23-04-2019 \\ Email: aroloyen@yahoo.com
}

\section{Introduction}

The growth of seedlings can signify underlying adaptation to environmental conditions. Within different population individuals that find suitable location not only increase their chances of survival to maturity, but also pass on the good genes to the next generation (Duke et al., 1997). Therefore, with time seeds of individuals that show greater competitive ability dominate a given locality. This adaptation by the majority of the individuals to select a favorable soil condition is reflected in the local pattern of seed distribution, abundance and growth. Mangroves are amongst the most widespread marine vascular plants along subtropical and tropical coastlines (Sanchez, 2019). They grow in swampy soils (Feller et al., 2010), which originates from weathered sedimentary rocks (SPDC, 1999). The soil is a mixture of litter at different stages of decomposition (Numbere and Camilo, 2016) and serves as carbon sinks (Ong and Gong, 2013; Tam and Wong, 1995).

Nypa palm (Nypa fruticans) on the other hand, is regarded as a member of the mangrove ecosystem and from the nypoid line (Gee, 2001). However, other studies had shown that nypa palm is not a true mangrove (Kathiresan and Bingham, 2001). Nypa palms are invasive species that are deliberately introduced into the Niger Delta to curb coastal erosion (CEDA, 1997; Keay et al., 1964). but have become a major threat to the mangroves. They grow in mangrove soils and have their seeds dispersed across the mangrove forest by tidal currents, signaling readiness for full colonization. During low tides the seeds of the palms settle down on the forest 
floor and start to grow. The growth of nypa palms within the mangrove forest endangers the mangroves and prevents them from attaining maturity. This is because the palms compete for space and nutrients with the mangroves. The palms use their tiny, permeable and fibrous root system to absorb soil minerals. They also produce allelochemicals, which prevents the growth of other plants around them (Numbere, 2018). Apart from edaphic factors, which affects soil properties, anthropogenic factors also contribute to rapid changes in soil composition and soil chemistry, For instance, oil and gas exploration lead to hydrocarbon pollution (James et al., 2007; Kathiresan and Bingham, 2001) and affects soil chemistry (Levin et al., 2006; Alongi, 2009). In the same vein, deforestation of mangrove trees to pave way for exploration activity (Numbere, 2018) impact mangrove growth (Chakraborty, 2019) leading to reduction in species abundance. It is thus postulated that the rapid growth of palms in mangrove forests may signify their affinity and adaptation to mangrove soil. The purpose of this study was to determine the growth rate of mangrove and nypa palm seedlings in different soils and to determine the distribution and abundance of seedlings of both species in a deforested mangrove forest. The objectives were (1) to compare growth of mangrove and nypa palm seedlings in mangrove, nypa palm and farm soils, (2) to determine the survival of mangrove and nypa palm seedlings in different soils (3) to determine the abundance of mangrove and nypa palm seedlings in deforested mangrove forest.

\section{Methods}

\section{Study Areas}

Soil samples were collected at three sites in two study locations in the Niger Delta in 2015 as follows: crop farm in Ozuoba $\left(4^{\circ} 52^{\prime} \mathrm{N}\right.$ and $\left.6^{\circ} 55^{\prime} \mathrm{E}\right)$, mangrove and nypa palm forest in Okrika $\left(04^{\circ} 43^{\prime} \mathrm{N}\right.$ and $\left.7^{\circ} 05^{\prime} \mathrm{E}\right)$ (Fig. 1). The climate of the area is monsoonal and the precipitation at the study location, which was measured daily with a rain gauge from July 2015 to June, 2016 was $1466 \mathrm{~mm}$. The rain began in March and attained its peak in May while the dry months began in November and ended in February. The mean annual temperature range recorded at the experimental station was between $26-28^{\circ} \mathrm{C}$. The mangrove forest near the refinery is uniquely divided into two sections by a connecting tarred road ( $\sim 4.6 \mathrm{~m}$ wide) that leads from the refinery to the jetty, where crude oil is evacuated into ships. Ten sets of giant Nickel/Steel alloy crude oil pipelines (i.e., 8-10 inches wide) that spans about $16 \mathrm{~km}$ in length and convey crude oil and petroleum products from the refinery to the jetty are found $1 \mathrm{~m}$ away from the road. The tarred road creates an artificial partitioning of the mangrove forest into highly ( $\sim 20 \mathrm{~m}$ from the pipelines) and lowly ( $\sim 100 \mathrm{~m}$ from the pipelines) polluted treatments. Highly polluted treatment has higher Total Hydrocarbon Content (THC) while lowly polluted treatment has lower THC concentration (Table 1). Details of the study location are given in previous studies (Numbere, 2014; Numbere and Camilo, 2017).

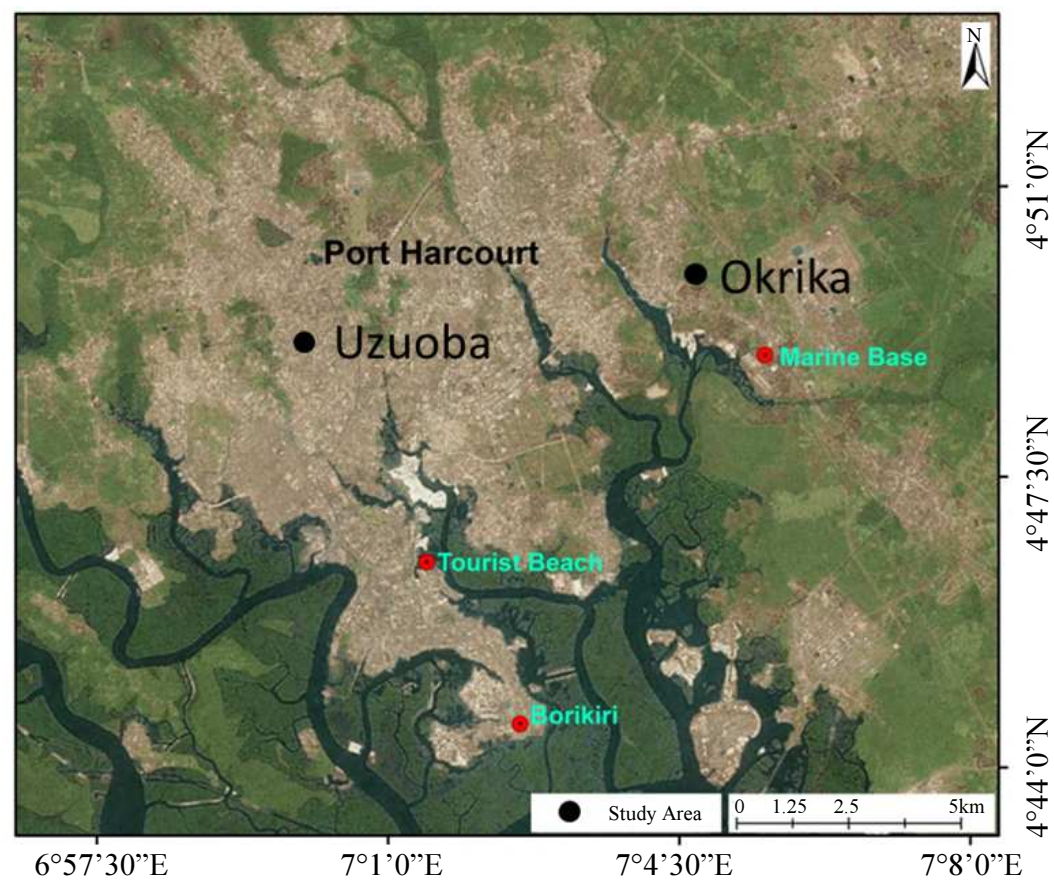

Fig. 1: (a) Map of study area. The map shows mangrove forest (green) and urban areas (non-green) in the Niger Delta region 
Table 1: Soil physico-chemical characteristics of different soils collected at different locations in the Niger Delta, Nigeria. Mangrove-high soil indicates highly polluted soil and mangrove low indicates lowly polluted soil

\begin{tabular}{|c|c|c|c|c|c|c|}
\hline \multirow[b]{2}{*}{ Soil properties } & \multicolumn{6}{|l|}{ Soil types } \\
\hline & Mangrove-high & Mangrove-low & Nypa & Farm & $\mathrm{F}$ & $\mathrm{P}$ \\
\hline $\mathrm{Ph}$ & $6.0 \pm 0.1$ & $6.2 \pm 0.1$ & $5.8 \pm 0.1$ & $6.9 \pm 0.1$ & 0.1 & 0.30 \\
\hline Organic matter (\%) & $1.01 \pm 0.01$ & $1.48 \pm 0.05$ & $1.87 \pm 0.01$ & $1.99 \pm 0.01$ & 0.3 & $0.02 *$ \\
\hline $\mathrm{THC}\left(\mathrm{mgkg}^{-1}\right)$ & $738.5 \pm 109.3$ & $220 \pm 6.0$ & $147.6 \pm 21.3$ & $72 \pm 18.0$ & 0.2 & $0.03 *$ \\
\hline Soil compaction $\left(\mathrm{kg} / \mathrm{cm}^{2}\right)$ & $0.25 \pm 0.01$ & $0.30 \pm 0.02$ & $0.90 \pm 0.1$ & $1.5 \pm 0.1$ & 0.2 & $0.01 *$ \\
\hline Temperature $\left({ }^{\circ} \mathrm{C}\right)$ & $24.6 \pm 0.1$ & $24.9 \pm 0.1$ & $24.7 \pm 0.1$ & $25.5 \pm 0.1$ & 0.3 & 0.10 \\
\hline
\end{tabular}

*significant

\section{Study Species}

Rhizophora racemosa (Rhizophoracea) is the dominant species of mangroves that grows in the study area. It grows mainly in soils that are swampy and filled with organic material such as leave litter. It has adventitious root system that supports survival under anaerobic condition (Kathiresan and Bingham, 2001). The mangrove forest supports numerous organisms and provides some ecosystem services such as food, medicinal herbs, fire wood and building materials (Polidoro et al., 2010). Rhizophora propagule is torpedoshaped and is the longest (length: $9.4 \mathrm{~cm}$ ) and heaviest seed (134 g) amongst the two other prominent mangrove species (i.e., white: Avicennia germinans; and black: Laguncularia racemosa).

Nypa palm, Nypa fruticans (Palmae) is the second most dominant species after the mangroves species in the area (CEDA, 1997; Keay et al., 1964). The palms are invasive species (Johnstone, 1996) that have colonized vast areas of the mangrove forests in the last 20 years (Wang et al., 2016; Numbere, 2018). They have fibrous root system and are ubiquitous in disturbed soils that have been infiltrated with human waste. Their seeds are round and made up of fibrous foam-like outer covering that makes them buoyant and scattered on forest floor.

\section{Sample Collection}

Soil samples were collected with hand-held soil augur (Scotts, Germany) from a depth of $5 \mathrm{~cm}$ below the soil surface at five randomly selected spots each in farm, nypa palm, highly polluted mangrove (i.e., mangrove-high) and lowly polluted mangrove (i.e., mangrove-low) soils. The specific areas of soil collection were geo-referenced with Garmin GPS (USA). The mangrove soil is coffee brown in color, semi-muddy and soft. The nypa palm soil is light chocolate-brown in color, muddy, soft and filled with organic materials while farm soil is light brown in color, sandy-loam, porous slightly coarse and contain plant litter. The farm soil is dark brown and was used as the control (Fig. 2).

Soil $\mathrm{pH}$ was determined with a Kelway soil tester while the soil compaction was determined with a pocket penetrometer. Soil temperature was determined with a digital dual sensor thermometer to a detection limit of
$+/-1{ }^{\circ} \mathrm{C}$. Salinity of the surrounding water body was determined with a salinity meter (OAKTON salt 6, Acorn series) to a detection limit of $+/-1 \%$. Twenty seeds each of mangrove and nypa palm were picked from the forest floor or plucked from the trees. Those without blemish were selected, cleaned and weighed (Ohause model SC 2020) and their lengths measured with a measuring tape (Keson OTR10M300). The diameter was measured with a vernier caliper (Science ware, Switzerland) at an accuracy of $0.1 \mathrm{~mm}$.

\section{Laboratory Analysis}

\section{Total Hydrocarbon Content (THC) and Total Organic Content (TOC) Analysis}

Total Hydrocarbon Content (THC) was determined using colorimetric method (model: DR $890 \mathrm{HATCH}$ colorimeter) and Total Organic Content (TOC) was determined using Walkey-Black titrimetric method. The THC was used to determine the level of pollution of the soil types in other to delineate the area into highly and lowly polluted soils (Numbere and Camilo, 2016). The TOC was used to determine the nutrient content in the soil. This is because soil organic content influence soil texture and composition, which affects mangrove growth (Alongi, 2009).

\section{Experiment 1: Seedling Growth and Survival in Nursery}

The average initial weight, diameter and length of nypa palm (133.9 g, $4.9 \mathrm{~mm}$ and $9.4 \mathrm{~cm})$ and mangrove (i.e., $9.4 \mathrm{~g}, 1.1 \mathrm{~mm}$ and $17.4 \mathrm{~cm}$ ) seedlings were recorded before they were planted.

Both seeds were planted in a combination of ten seedlings per four soil types for mangrove and nypa palm in a combination of $10 \times 4 \times 2$, which gives a total of 80 replications (Fig. 3a). The mangrove and nypa palm seedlings were planted in medium-sized polyethylene bags $(32 \mathrm{~cm} \times 22 \mathrm{~cm} \times 14 \mathrm{~cm})$ and placed in a $0.8 \mathrm{~m} \times 1.3 \mathrm{~m}$ swamp box (Numbere and Camilo, 2017). The bags were filled to the brim with four soil types up to a volume of $9856 \mathrm{~cm}^{3}$. The mangrove seedlings were planted upright with the bottom sticking into the soil to a depth of $5 \mathrm{~cm}$ while the nypa palm seedlings were buried in the soil with the growing bud facing upward and the roots facing downwards into the soil. 


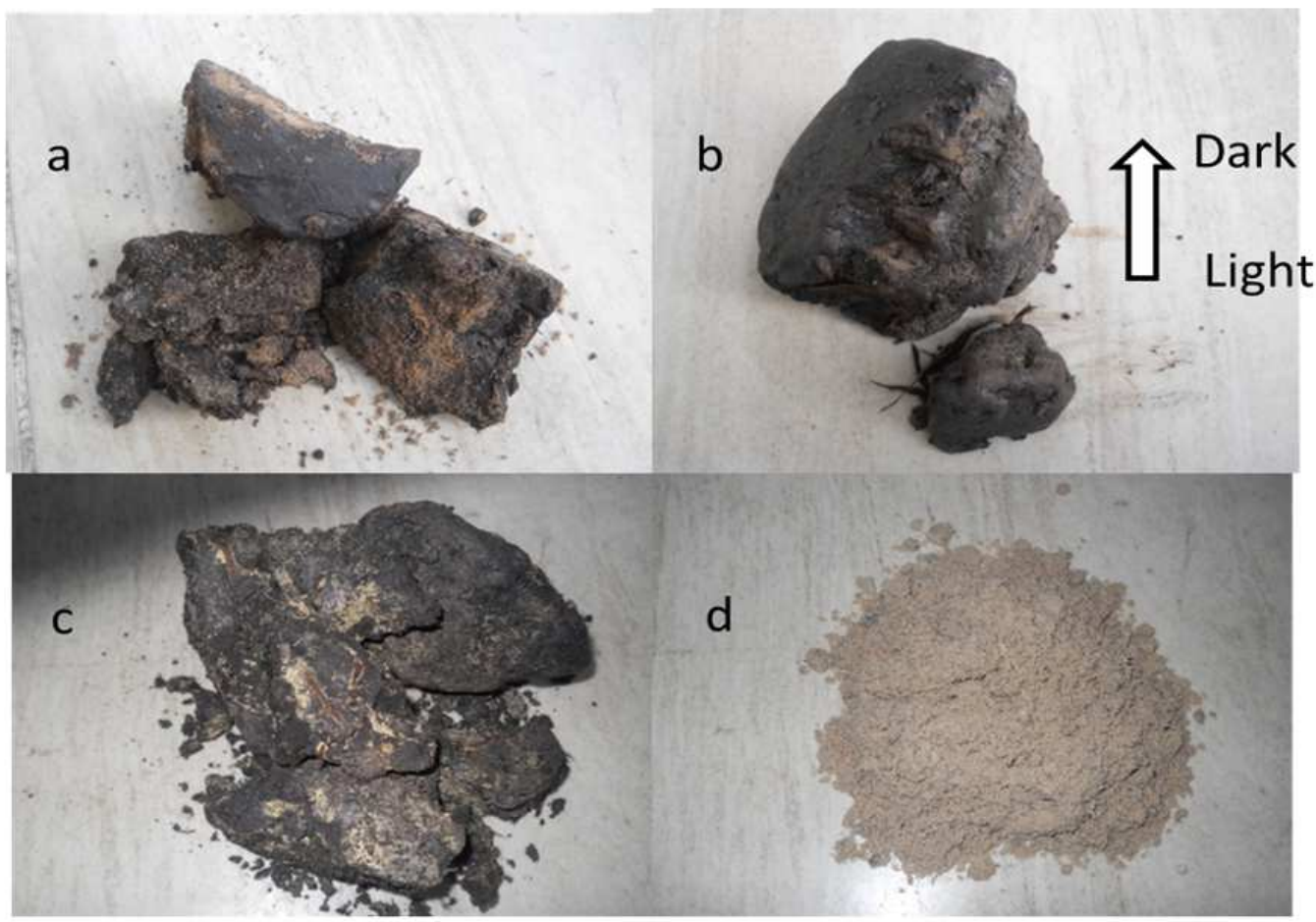

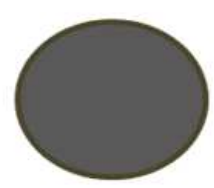

$2-7.5 \mathrm{~mm}$

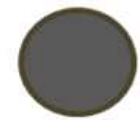

$0.05-2 \mathrm{~mm}$

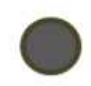

$0.002-0.5 \mathrm{~mm}$
$<0.002 \mathrm{~mm}$

Fig. 2: Four soil types found in the mangrove wet land areas of the Niger Delta, Nigeria: (a) Nypa palm soil (Muddy); (b) Mangrove (chikoko-wet); (c) mangrove (Chikoko-dry) and (d) Sandy soil. It show the soil mineral particles

Semi-natural conditions were simulated in the nursery by allowing the seedlings to grow in the open under the elements of the weather. The seedlings were watered daily with river water of salinity $26.4 \mathrm{ppt}$.

Height, number of leaves and diameter of seedlings were measured between June 2015-June 2016. The height of the mangrove seedlings was measured as the distance between the tip of the sprouting bud and the base of the seedling while the diameter was measured as the circumference of the leave stalk taken $5 \mathrm{~cm}$ from the bottom. Similarly, the height of the nypa palm seedlings was measured as the length of the longest newly sprouting leave. Mangrove started growing one month after planting whereas nypa palm started growing 2-3 months after planting.

Survival of mangrove and nypa palm seedlings was determined by the number of seedlings that were alive in the different soil types at the end of one year. Survival rate $\left(S_{x}\right)$ was calculated based on the number of seedlings alive from 0 -I year $\left(N_{x}\right)$ using Equation 1:

$$
S_{x}=\frac{N_{x}+1}{N_{x}}
$$

\section{Experiment 2: Seedling Abundance in Deforested Mangrove Forest}

Five randomly selected points were generated (Fig. 3b) using the spa package in R Development Core Team (2014) and the average abundance of seed and seedlings estimated (Logan, 2010). The study area was mangrove dominated, but because of several years of deforestation activities there are some gaps in the forest. The experiment did not include mature trees, but only considered seed and seedlings of mangroves and nypa palms at different stages of growth. A total of 354 seedlings were counted and divided into four size classes as follows: (1) seeds (no size range), (2) small seedlings $(\leq 0.3 \mathrm{~m}),(3)$ medium seedlings $(>0.3 \mathrm{~m}$ or $\leq 0.6 \mathrm{~m})$ and (4) large seedlings $(>0.6 \mathrm{~m})$. 


\begin{tabular}{|c|c|c|c|c|c|c|c|c|}
\hline \multirow{2}{*}{ (a) } & \multicolumn{4}{|c|}{ Mangrove seedlings } & \multicolumn{4}{|c|}{ Nypa palm seedlings } \\
\hline & $\mathrm{F}$ & M-H & M-L & $\mathrm{N}$ & $\mathrm{F}$ & M-H & M-L & $\mathrm{N}$ \\
\hline \multirow{10}{*}{$0.8 \mathrm{~m}$} & $\mathrm{O}$ & $\mathrm{O}$ & $\mathrm{O}$ & $\mathrm{O}$ & $\mathrm{O}$ & $\mathrm{O}$ & $\mathrm{O}$ & $\mathrm{O}$ \\
\hline & $\mathrm{O}$ i & $\mathrm{O}$ & $\mathrm{O}$ & $\mathrm{O}$ & $\mathrm{O}$ & $\mathrm{O}$ & $\mathrm{O}$ & $\mathrm{O}$ \\
\hline & $\mathrm{O}$ & $\mathrm{O}$ & $\mathrm{O}$ & $\mathrm{O}$ & $\mathrm{O}$ & $\mathrm{O}$ & $\mathrm{O}$ & $\mathrm{O}$ \\
\hline & $\mathrm{O} \stackrel{0}{0}$ & $\mathrm{O}$ & $\mathrm{O}$ & $\mathrm{O}$ & $\mathrm{O}$ & $\mathrm{O}$ & $\mathrm{O}$ & $\mathrm{O}$ \\
\hline & $\mathrm{O}$ 远 & $\mathrm{O}$ & $\mathrm{O}$ & $\mathrm{O}$ & $\mathrm{O}$ & $\mathrm{O}$ & $\mathrm{O}$ & $\mathrm{O}$ \\
\hline & 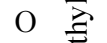 & $\mathrm{O}$ & $\mathrm{O}$ & $\mathrm{O}$ & $\mathrm{O}$ & $\mathrm{O}$ & $\mathrm{O}$ & $\mathrm{O}$ \\
\hline & $\mathrm{O} \stackrel{ \pm}{2}$ & $\mathrm{O}$ & $\mathrm{O}$ & $\mathrm{O}$ & $\mathrm{O}$ & $\mathrm{O}$ & $\mathrm{O}$ & $\mathrm{O}$ \\
\hline & $O=$ & $\mathrm{O}$ & $\mathrm{O}$ & $\mathrm{O}$ & $\mathrm{O}$ & $\mathrm{O}$ & $\mathrm{O}$ & $\mathrm{O}$ \\
\hline & $\mathrm{O}^{-}$ & $\mathrm{O}$ & $\mathrm{O}$ & $\mathrm{O}$ & $\mathrm{O}$ & $\mathrm{O}$ & $\mathrm{O}$ & $\mathrm{O}$ \\
\hline & $\mathrm{O}$ & $\mathrm{O}$ & $\mathrm{O}$ & $\mathrm{O}$ & $\mathrm{O}$ & $\mathrm{O}$ & $\mathrm{O}$ & $\mathrm{O}$ \\
\hline
\end{tabular}

(b)

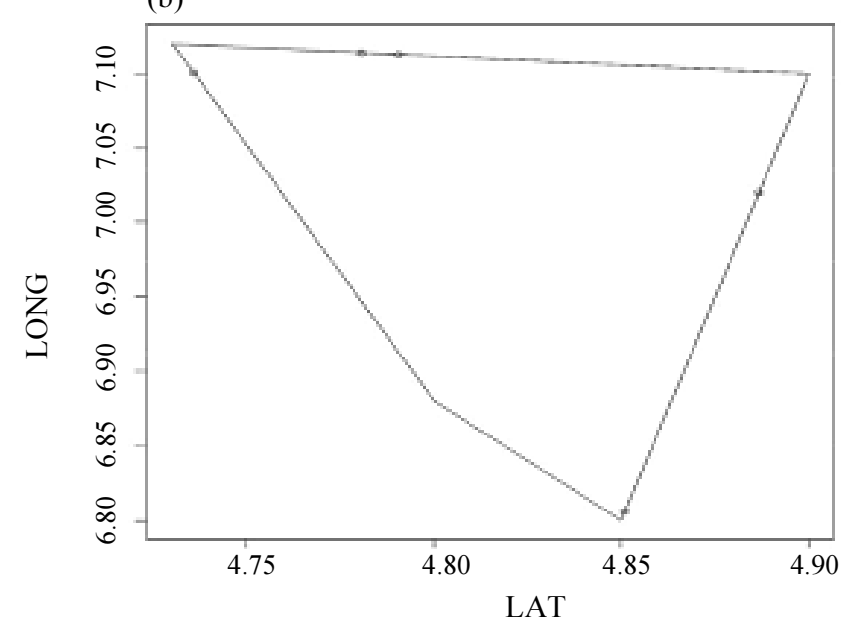

Fig. 3: (a) Experimental design of ( a) one unit of seedling growth experiment in polyethylene bags placed in a $1.3 \mathrm{~m} \times 0.8 \mathrm{~m} \mathrm{swamp}$ box ( $\mathrm{n}=80$ seed and seedling samples), (b) Five randomly selected locations in a deforested forest where seedlings were enumerated in a $20 \mathrm{~m} \times 20 \mathrm{~m}$ plot $(\mathrm{n}=354$ seed samples $)$. Where $\mathrm{F}=$ farm soil, $\mathrm{M}-\mathrm{H}=$ mangrove high soil. $\mathrm{M}-\mathrm{L}=$ mangrove low; $\mathrm{N}=$ Nypa pal soil; LAT represents latitude while LONG represent

\section{Statistical Analysis}

Normality and homoscedasticity of variance test were conducted (Logan, 2010) (Fig. 4a). To ensure that population group means are equal, an analysis of variance (ANOVA) of mangrove and nypa palm growth versus different soil types were conducted (Quinn and Keough, 2002). Tukey's test was performed to investigate pair wise mean differences between groups (Zar, 1996). Abundance experiment was analyzed with a one-way ANOVA to test whether there was a significant difference in seed abundance between mangrove and nypa palm and also whether there was difference in the abundance of the different growth stages. Here the growth stages were regarded as the independent variables while the number of seedlings was regarded as the dependent variables for both species. All analyses were performed in R statistical environment, 3.1.2 (R Development Core
Team, 2014). Bar graphs were plotted to show the relationship of all parameters and their significance.

\section{Results}

\section{Effect of Soil on Growth and Survival}

Mangrove propagules were the first to produce leaves between three weeks to one month after planting, but were the first to die within a year. Nypa palm seedlings produced no leaf after one month. The organic content of farm soil was the highest $(1.99 \pm 0.01 \%)$ followed by nypa palm $(1.87 \pm 0.01 \%)$, mangrove-low $(1.48 \pm 0.05 \%)$ and mangrove-high $(1.01 \pm 0.01 \%)$ soils (Table 1$)$. The Total Hydrocarbon Content (THC) was higher in mangrove-high soil $\left(738.5 \pm 109.3 \mathrm{kgcm}^{-2}\right)$ as compared to farm soil $\left(72 \pm 8 \mathrm{kgcm}^{-2}\right)$ in line with an earlier study (Numbere, 2014). Height of seedlings $\left(\mathrm{F}_{3,162}=4.54\right.$, $P<0.001$, Fig. 4b) and number of leaves $\left(\mathrm{F}_{3,162}=21.52\right.$, 
$P<0.0001$, Fig. 4c) of mangroves in different soils were significantly different, but diameter of seedlings were decidedly not different $\left(\mathrm{F}_{3,162}=4.54, P=0.06\right)$. Height of mangrove seedlings were more influenced by soils from highly polluted plot $(P=0.027)$ while number of leaves were more influenced by farm soil $(P=0.0001)$. Mangrove seedlings planted in farm soil were taller $(7.8 \pm$ $0.7 \mathrm{~cm})$ than seedlings planted in highly polluted soil $(7.7 \pm 0.4 \mathrm{~cm})$, lowly polluted soil $(6.3 \pm 1.4 \mathrm{~cm})$ and nypa palm soil $(6.0 \pm 0.8 \mathrm{~cm})$. Mangrove propagules planted in farm soils also had the highest number of leaves (6).

For nypa palms, height of seedlings $\left(\mathrm{F}_{3,157}=9.33\right.$, $P<0.0001)$ and number of leaves $\left(\mathrm{F}_{3}, 162=19.37\right.$, $P<0.0001)$ in different soils were significantly different. Nypa palm seedlings planted in farm soil were decidedly the tallest $(42 \pm 3.4 \mathrm{~cm})$ followed by seedlings grown in mangrove-high $(38.8 \pm 5.8 \mathrm{~cm})$, mangrove-low $(34.2 \pm \mathrm{cm})$ and nypa palm $(21.1 \pm 1.0 \mathrm{~cm})$ soils.
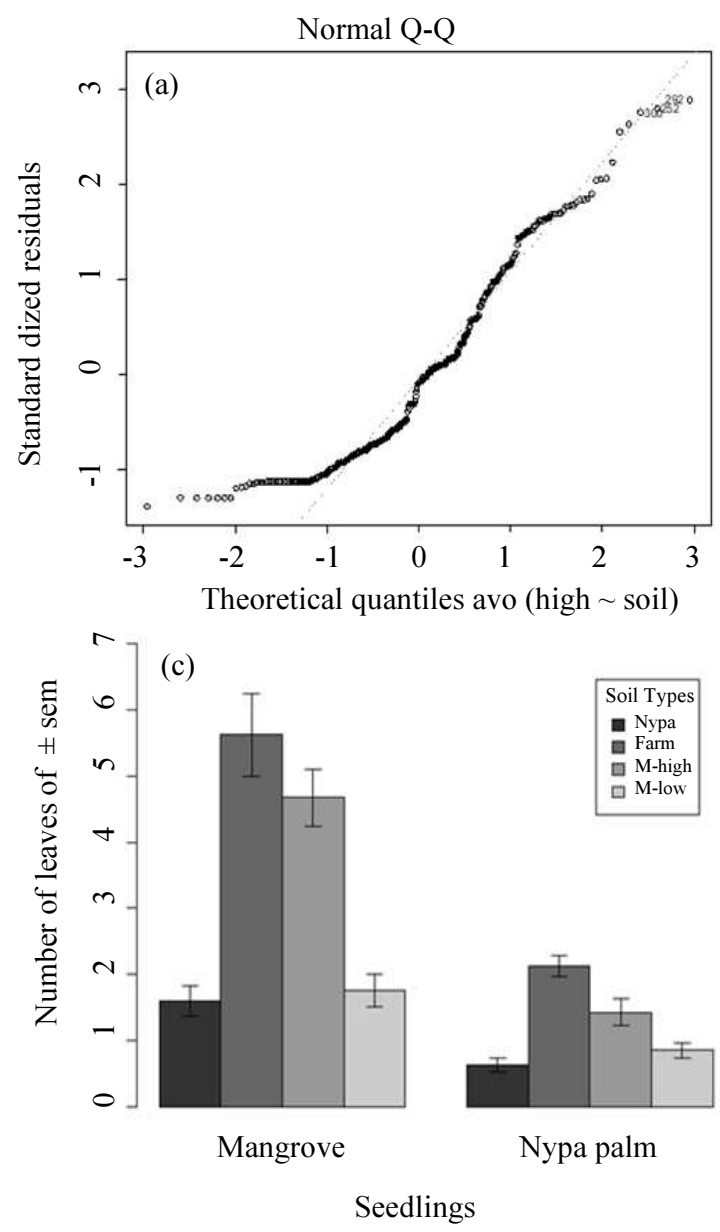

\section{Species Distribution and Abundance}

The species abundance of the different growth stages of mangrove and nypa palm seedlings were significantly different $\left(\mathrm{F}_{1,37}=3.07, P=0.04\right)$. Small to large mangrove seedlings were obviously more than small to large nypa palm seedlings and nypa palm seed population was more than mangrove seed population (Fig. 4d) in a ratio of 27:1.

Although, there was no significant difference in the rate of survival between mangrove and nypa palm seedlings $\left(\mathrm{F}_{1,6}=0.47, \mathrm{P}>0.05\right)$; nypa palm seedlings had higher overall survival rate $(0.48)$ than mangroves seedlings (0.35) in different soil types. Surprisingly, nypa palm seedlings had higher survival rate in mangrove soil than its own soil. But mangrove seedlings are site specific and survived more in their own soil and farm soil (Fig. 5).
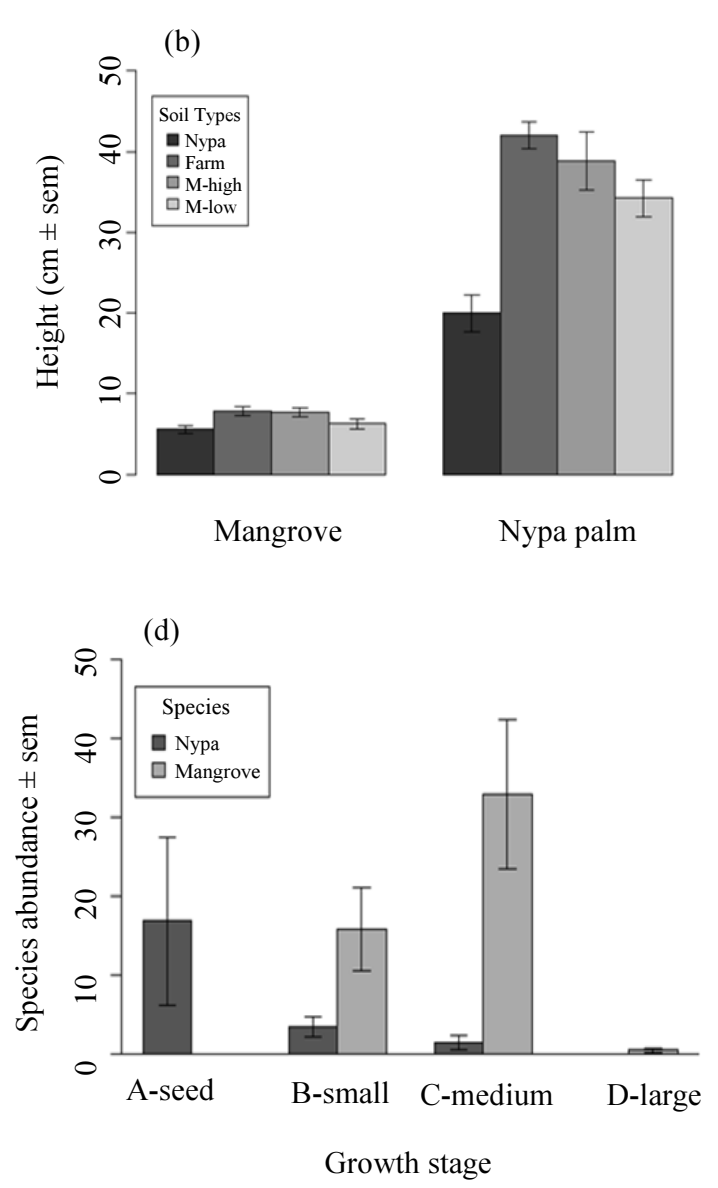

Fig. 4: (a) Normal Q-Q graph to show that height data was normalized (b) Mean height and (c) number of leaves of mangrove (Rhizophora racemosa) and nypa palm (Nypa fruticans) seedlings grown in different soils in the Niger River Delta, Nigeria. M-high indicates highly polluted soil while M-low indicates lowly polluted soil (d) Abundance of seeds and different growth stages of mangrove and nypa palms in a deforested mangrove forest in the Niger River Delta, Nigeria. Vertical lines show 1 standard error of the mean 


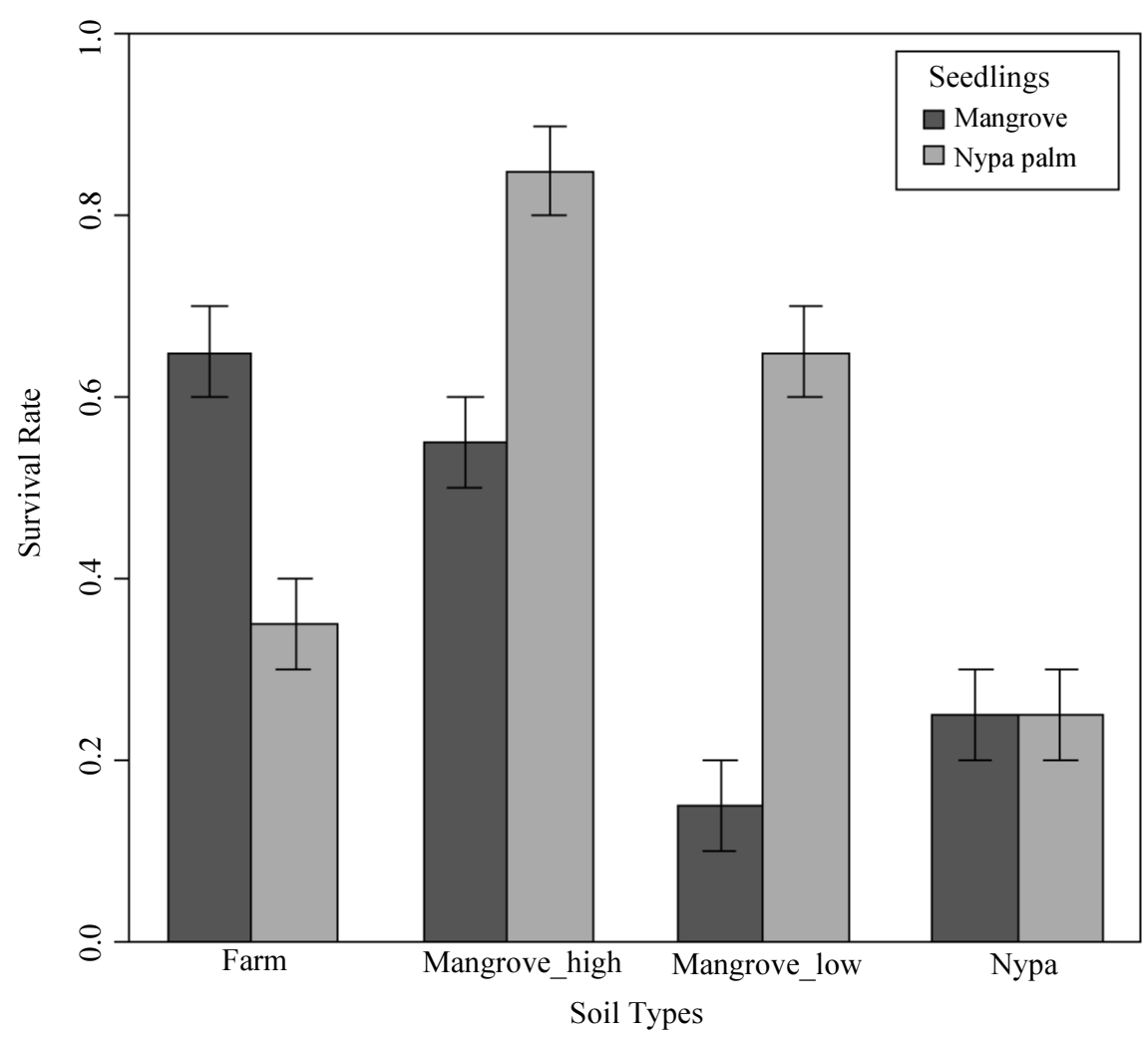

Fig. 5: Graph of mean of survival rate of mangrove and nypa palm seedlings: Survival rate of mangrove and nypa palm seedlings in farm, mangrove-high, mangrove-low and nypa palm soils in nursery

\section{Discussion}

Different soil types influenced the height and number of leaves of mangroves and nypa palm seedlings (Fig. 4a and 4b). But mangrove seedlings are quick starters being viviparous while nypa palm seedlings are slow starters based on the longer time they take to germinate. The height of mangrove seedling is influenced by the source of soil. Nypa palm seedlings had better growth and survival in different soils apart from its own soil (Fig 5). Nypa palm also has high seedling abundance and distribution, which has made its colonization of mangrove forest successful. The invasion of the palms is accelerated by soil quality change caused by human activities such as oil spillages, waste disposal and urbanization, which had perturbed the mangrove soil for decades. Farm and nypa palm soils are rich in organic content than mangroves soils as a result of the presence of manure especially during harvesting season and disposal of municipal waste in nypa palm forest (Table 1). This is precipitated by high human population around mangrove forest. The increased entry of organic waste into mangrove forest results in the conversion of swampy soil to muddy soil. This change affects the growth of mangroves and makes them poor competitors to the palms. Mangrove soil is dark brown in color because of increased litter fall and decomposition. It also has low plasticity and high porosity. In contrast, nypa soil is light brown in color, muddy and has low litter activity. It also has high plasticity and low porosity, which are qualities that are not conducive for mangrove growth. Mangroves and nypa palm seedlings performed well in farm soil because it has high nutrient content (e.g., nitrogen and phosphorous). Although, mangroves are poor utilizers of nitrogen, restoration projects utilize fertilizers, which basically contain Nitrogen, Phosphorous and Potassium (NPK) to facilitate their growth in seed bed. This implies that farm soil can also be used in mangrove restoration project, if done in combination with other factors that facilitate mangrove growth such as increased salinity, low plasticity and high carbon content. Mangrove seedlings introduced into nypa palm soils have poor growth because of a deficit in nutrient content and poor adaptation while in contrast the movement of nypa palms seedlings into mangrove soil is advantageous to the palms, whose root morphology and physiology permits better nutrient absorption and translocation as compared to the mangroves that have hardened and less permeable root system. 


\section{Conclusion}

High abundance and distribution of nypa seeds in deforested mangrove forest (Fig. 4d) signify early stage of colonization, which is facilitated by propagule pressure. This is as a result of the window of opportunity created by the deforestation of mangroves. This situation has been a major factor in the overall decline of mangrove forest in the Niger Delta region. This study therefore, suggests that since soil plays key role in mangrove growth, there should be constant monitoring of soil quality to forestall drastic changes that will jeopardize the survival of the mangroves. Nypa palm seedlings should also be physically removed from mangrove forest to prevent colonization. In addition, more mangrove seeds should be planted in deforested mangrove areas to close the window of opportunity for the palms. The outcome of this study implies that soil quality is very significant to mangrove restoration in deforested and polluted areas globally.

\section{Acknowledgements}

We thank our research assistants Mr. Chimezie Brown Iwuji who assisted in sample collection. We also thank the undergraduate mentor of the lead author, Professor Emeritus S.N. Okiwelu, who is assistance in proof reading the work.

\section{Funding Information}

The researchers did not receive any funds from any funding agency for this project. The study was independently carried out by the author at the Department of Animal and Environmental Biology, University of Port Harcourt, Nigeria

\section{Author's Contributions}

Aroloye O. Numbere: Solely initiated the conceptual and experimental design, collected data, performed the statistical analysis and wrote the manuscript.

\section{Conflict of Interest}

The author has no conflict of interest to declare.

\section{Ethics}

This article is original and contains unpublished material. The corresponding author confirms that all of the other authors have read and approved the manuscript no ethical issues involved.

\section{References}

Alongi, D.M., 2009. Energetics of mangrove forests, 1st Edn., Springer Science and Business Media, New York USA, ISBN-10: 140204271X, pp: 216.
CEDA, 1997. Coastal profile of Nigeria, Abuja. Federal Environmental Protection Agency.

Chakraborty, S.K., 2019. Bioinvasion and Environmental Perturbation: Synergistic Impact on Coastal-Mangrove Ecosystems of West Bengal, India. In: Impacts of Invasive Species on Coastal Environments, Makowski, C., C. Finkl (Eds.), Springer, Cham, ISBN-10: 978-3-319-91382-7, pp: 171-245.

Duke, N.C., M.Z.S. Pinzon and T.M.C. Prada, 1997. Large-scale damage to mangrove forests following two large oil spills in Panama. Biotropica, 29: 2-14. DOI: 10.1111/j.1744-7429.1997.tb00001.x

Feller, I.C., C.E. Lovelock, U. Berger, K.L. McKee and S.B. Joye et al., 2010. Biocomplexity in Mangrove Ecosystems, Annu. Rev. Mar. Sci., 2: 395-417.

Gee, C.T., 2001. The mangrove palm nypa in the geologic past of the new world. Wetlands Ecol. Manage., 9: 181-194. DOI: 10.1023/a: 1011148522181

James, G.K., O. Adegoke, E. Saba, P. Nwilo and J. Akinyede, 2007. Satellite-based assessment of the extent and changes in the mangrove ecosystem of the Niger Delta. Mar. Geodesy, 30: 249-267. DOI: $10.1080 / 01490410701438224$

Johnstone, I.M., 1996. Plant invasion windows: A timebased classification of invasion potential. Biolo. Rev., 61: 324-337.

Kathiresan, K. and B.L. Bingham, 2001. Biology of mangrove ecosystems. Adv. Mar. Biol., 40: 81-251. DOI: 10.1016/s0065-2881(01)40003-4

Keay, R.W.J., C.F.A. Onochie and D.P. Standfield, 1964. Nigerian trees. Federal Department of Forestry Research, National Press Limited, Ibadan, Nigeria.

Levin, L.A., C. Neira and E.D. Grosholz, 2006. Invasive modifies wetland ecosystem function. Ecology, 87: 419-432. DOI: 10.1890/04-1752

Logan, M., 2010. Biostatistical Design and Analysis Using R: A Practical Guide. 1st Edn., John Wiley and Sons, England, ISBN-10: 144436247X, pp: 576.

Numbere, A.O. and G.R. Camilo, 2017. Mangrove leaf litter decomposition under mangrove forest stands with different levels of pollution in the Niger River Delta, Nigeria. Afr. J. Ecol., 55: 162-167. DOI: $10.1111 /$ aje. 12335

Numbere, A.O., 2014. Impact of hydrocarbon pollution on the mangrove ecosystem of the Niger River Delta, Nigeria. Ph.D. Thesis, PhD Dissertation, Saint Louis University, Saint Louis, Missouri.

Numbere, A.O., 2018. Impact of invasive nypa palm (Nypa fruticans) on mangroves in coastal areas of the Niger Delta Region, Nigeria. In: Impacts of Invasive Species on Coastal Environments. Coastal Research Library, Makowski, C., C. Finkl (Eds.), Springer, Cham, ISBN-10: 978-3-319-91382-7. pp: 425-454. 
Ong, J.E. and W.K. Gong, 2013. Structure function and management of mangrove ecosystems. ISME Mangrove Educational Book Series No. 2. International Society for Mangrove Ecosystems (ISME), Okinawa, Japan and International Tropical Timber Organization (ITTO), Yokohama, Japan.

Polidoro B.A., K.E. Carpenter, L. Collins, N.C. Duke and A.M. Ellison et al., 2010. The loss of species: mangrove extinction risk and geographic areas of global concern. PLoS one 5: e10095-e10095. DOI: 10.1371/journal.pone.0010095

Quinn, G.P. and K.J. Keough, 2002. Experimental Design And Data Analysis for Biologists. 1st Edn., Cambridge University Press, London. ISBN-10: 0521009766, pp: 537.

R Development Core Team, 2014. R: A language and environment for statistical computing. R Foundation for Statistical Computing, Vienna, Austria.

SPDC, 1999. EIA of Belema gas injection and oil field development project. Shell Petroleum Development Company.
Sanchez, P.A., 2019. Properties and Management of Soils in the Tropics. 1st Edn., Cambridge University Press, ISBN-10: 1107176050, pp: 690.

Sato, G., A. Fisseha, S. Gebrekiros, H.A. Karim, S. Negassi, M. Fischer, E. Yemane, J. Teclemariam and R. Riley, 2005. A novel approach to growing mangroves on the coastal mudflats of Eritrea with the potential for relieving regional hunger and poverty. Wetlands, 25: 776-779. DOI:10.1672/0277-5212

Tam, N.F.Y. and Y.S. Wong, 1995. Mangrove soils as sinks for waste waters borne pollutants. Hydrobiologia, 295: 231-241. DOI: $10.1007 / \mathrm{BF} 00029130$

Wang, P., A.O. Numbere and G.R. Camilo, 2016. Long term changes in mangrove landscape of the Niger River Delta, Nigeria. Am.. J. Environ. Sci, 12: 248259. DOI: 10.3844/ajessp.2016.248.259

Zar, J.H., 1996. Biostatistical Analysis. 5th Edn., Prentice, Upper Saddle River, New Jersey, ISBN-10: 1784488437, pp: 944. 